\title{
Mesin Penetas Telur Menggunakan Microcontroller ATMega328 Berbasis Arduino
}

\author{
Iwan Purnama ${ }^{1,2, *}$, Ambiyar², Fahmi Rizal' ${ }^{2}$, Unung Verawardina², Sutrino Dwi Raharjo', Abdul Karim ${ }^{3}$ \\ ${ }^{1}$ Fakultas Sains dan Teknologi, Prodi Teknologi Informasi, Universitas Labuhanbatu, Rantauprapat, Indonesia \\ ${ }^{2}$ Fakulas Teknik, Prodi Pendidikan Teknologi dan Kejuruan, Universitas Negeri Padang, Padang, Indonesia \\ ${ }^{3}$ Prodi Teknik Informatika, Universitas Budi Darma, Medan, Indonesia \\ Email: 1,*Iwanpurnama2014@gmail.com, ${ }^{2}$ ambiyar@ft.unp.ac.id, ${ }^{3}$ fahmi@ft.unp.ac.id, ${ }^{4}$ unungverawardina@ gmail.com, \\ ${ }^{5}$ sutrinodwiraharjo@gmail.com, ${ }^{6}$ abdkarim6@gmail.com \\ Email Penulis Korespondensi: iwanpurnama2014@gmail.com
}

\begin{abstract}
Abstrak-Tujuan penelitian ini adalah merancang dan mengimplementasikan alat penetas telur bebek. Mesin penetas telur merupakan mesin yang berfungsi untuk mengambil alih tugas mengerami dari seekor induk bebek dalam mengerami telur-telur yang dibuahi dari hasil persilangan atau perkawinan dengan pejantan. Mesin penetas yang ada bekerja dalam pengontrolan suhu, pembalikan rak telur, tetapi tidak menggunakan sistem penginformasian telur yang telah menetas. Dalam perancangan alat penetas telur bebek ini berbasis Arduino sebagai kontroler. Suhu yang digunakan harus diukur melalui ketahanan ruang atau pun ketahanan kira-kira telur tersebut menetas. Mikrokontroler yang digunakan adalah ATMega328 terintegrasi pada Arduino Uno, sensor suhu, sensor kelembaban, sistem pengatur kelembaban serta komponen pendukung lainnya dengan menggunakan Arduino. Pengujian dilakukan dengan melakukan perbandingan sensor suhu DS18B20 dengan Thermometer dengan selisih eror 0,15. Hasil dari penelitian ini adalah Perangkat dapat mengontrol suhu tidak melebihi dari $39{ }^{\circ} \mathrm{C}$ untuk melakukan penetasan telur. Perangkat memiliki 2 tombol penggunaan, yaitu yaitu tombol start (hijau) untuk melakukan perhitungan hari penetasan dan tombol reset (merah) untuk menghentikan perhitungan hari penetasan. Variabel hari yang telah berjalan tetap tersimpan di dalam EEPROM (Electrically Erasable Programmable Read-Only Memory) mikrokontroler sehingga jika terjadi pemutusan atau hilangnya sumber daya tegangan seperti mati listrik dan lain sebagainya. Kipas 12VDC pada perangkat menyala setiap 30 menit dan padam pada 30 menit berikutnya.
\end{abstract}

Kata Kunci: Mesin Penetas Telur; ATMega328; Arduino; Mikrokontroller

\begin{abstract}
The purpose of this study was to design and implement a duck egg incubator. An egg incubator is a machine that functions to take over the incubation task of a duck mother in incubating fertilized eggs from the result of crossing or mating with a male. The existing incubators work in temperature control, reversing the egg racks, but do not use an egg informing system that has been hatched. In designing this duck egg incubator based on Arduino as a controller. The temperature used must be measured by the resistance of the space or the approximate resistance of the eggs to hatch. The microcontroller used is the ATMega328 integrated on the Arduino Uno, temperature sensor, humidity sensor, humidity control system and other supporting components using Arduino. The test was carried out by comparing the DS18B20 temperature sensor with a Thermometer with an error difference of 0.15 . The result of this research is the device can control the temperature not exceeding $39^{\circ} \mathrm{C}$ for hatching eggs. The device has 2 usage buttons, namely a start button (green) to perform hatching day calculations and a reset button (red) to stop hatching day calculations. The day variable that has been running is still stored in the microcontroller EEPROM (Electrically Erasable Programmable Read-Only Memory) so that if there is a disconnection or loss of a voltage power source such as a power failure and so on. The 12VDC fan on the device turns on every 30 minutes and goes out for the next 30 minutes.
\end{abstract}

Keywords: Egg Incubators; ATMega328; Arduino; Microcontroller

\section{PENDAHULUAN}

Seiring perkembangan dan pertumbuhan penduduk yang sangat cepat di Indonesia ini berdampak pada tingkat konsumsi masyarakat yang meningkat, pada khususnya akan kebutuhan daging unggas maupun telurnya yang kaya akan sumber protein yang utama[1]. Hal ini harus diimbangi dengan persedian yang cukup untuk memenuhi ketersediaan pangan sehingga ketahanan pangan yang mengandung protein tinggi tetap terpenuhi. Salah satu jalan untuk mengatasinya yaitu dengan menggantikan peran mesin penetas telur konvensional yang ditingkatkan kemampuannya menjadi mesin penetas telur yang otomatis sehingga dalam proses penetasan telur menjadi lebih mudah, hemat dan praktis dengan hasil penetasan yang lebih baik. Alat penetas telur adalah ruangan tertutup yang dipanasi dengan aliran listrik atau pemanas buatan lainnya yang dipakai untuk mengerami dan menetaskan telur. Pengeraman dengan alat penetas dilakukan oleh peternak biasanya karena telur yang ditetaskan relatif banyak. Peternak yang bermodal besar biasanya lebih memilih menggunakan alat penetas karena lebih efektif dan efisien. Biasanya alat penetas telur dilengkapi dengan pemanas, pemutar telur, dan sensor suhu sehingga suhu yang terdapat pada alat penetas telur dapat distabilkan.

Penetasan telur menjadi popular ditingkat peternakan kecil dan menengah dan bahkan ditingkat rumah tangga untuk dijadikan jenis petelur, pedaging untuk menghasilkan unggasunggas yang cantik untuk dipelihara sebagai bahan peliharaan. Akan tetapi para peternak sampai saat ini masih banyak yang menggantungkan untuk mendapatkan telur yang berkulitas dari hasil persilangan telur-telur unggul dan murni dari breeder (perusahaan penetasan telur). Dari semua tahap-tahap penetasan telur ada 5 poin utama yang harus diperhatikan pada inkubator mesinpenetas telur, yaitu :

1. Suhu (Temperatur) 
ISSN 2614-5278 (media cetak), ISSN 2548-8368 (media online)

Available Online at https://ejurnal.stmik-budidarma.ac.id/index.php/mib DOI 10.30865/mib.v5i2.2816

2. Kelembaban udara (Humidity)

3. Ventilasi (Ventilation)

4. Kebersihan (Cleanlinnes)

Penelitian tentang alat penetas telur pernah dilakukan oleh [2], penelitian tersebut merancang alat penetas telur menggunakan temperatur dan kelembaban menggunakan sensor DHT11. Untuk pemanas penetas digunakan 4 buah lampu dengan daya 20 Watt.Ruangan penetas juga dilengkapi dengan 1 buah kipas untuk sirkulasi udara. Mesin tetas yang memiliki kapasitas 2 rak ini dapat menampung 140 butir telur, sehingga bisa didapatkan telur ayam dalam jumlah banyak dalam waktu bersamaan. Hasil yang diperoleh dari 8 telur ayam yang ditetaska yaitu 6 ayam menetas dan 2 gagal, sehingga persentase keberhasilannya $75 \%$.

Arduino adalah sebuah sebuah tool atau papan elektronik yang dilengkapi dengan software open source yang menggunakan keluarga mikrokontroler ATMega dan berfungsi sebagai pengendali mikro single-board[3]. Arduino sudah dimanfaatkan untuk sistem kendali air[4], sistem kontrol dengan handphone [5], sistem kontrol peralatan listrik berbasis web[6], sistem kendali lampu rumah [7], sistem kontrol listrik prabayar [8], sistem kontrol suhu[9], Sistem kontrol penerangan[10] dan lainnya.

Selanjutnya pada [11], merancang sistem pengendalian suhu otomatis menggunakan arduino sebagai pengendali utamanya. Sensor suhu dan kelembaban menggunakan DHT22 pada kandang ayam dan driver motor L298 sebagai driver motor DC dan menggunakan logika fuzzy. Peranan fuzzylogic pada pengendalian suhu kandang ayam yaitu untuk mengatur PWM lampu supaya suhu pada kandang ayam tetap terjaga pada nilai set point yang diberikan. Pada perancangan sistem pengendalian suhu kandang ayam ini hasil yang didapat untuk mendapatkan nilai set point cukup lama sekitar 15 menit dikarenakan pemanas atau heater memiliki watt yang kecil.

\section{METODOLOGI PENELITIAN}

Pada bagian ini akan membahas tentang metode penelitian. Adapun tahapan-tahapannya adalah sebagai berikut:

\subsection{Analisis Masalah}

Dalam perancangan dan implementasi alat penetas telur bebek berbasis Arduino menggunakan beberapa metode rancang bangun yang pembuatannya terdapat beberapa masalah yang harus dipecahkan. Permasalahanpermasalahan tersebut antara lain :

a. Pengaturan Suhu (Temperatur)

b. Pengaturan Kelembaban Udara (Humidity) dan Ventilasi (Ventilation)

c. Kebersihan Cangkang Telur

\subsection{Strategi Pemecahan Masalah}

Ada beberapa permasalahan yang terjadi dalam perancangan dan implementasi alat penetas telur bebek berbasis arduino, maka dibutuhkan solusi atau pemecahan masalah, antara lain:

a. Pengaturan suhu inkubator menggunakan lampu pijar 12 VDC yang dapat dikendalikan (hidup/mati) untuk menjaga suhu inkubator, jika suhu melebihi batas normal, maka lampu dipadamkan dan sebaliknya.

b. Untuk mengatur kelembaban, bagian bawah inkubator diletakkan wadah berisi air dan sistem ventilasi menggunakan kipas 12 VDC untuk sirkulasi udara.

c. Sebelum masuk kedalam inkubator, telur dibersihkan terlebih dahulu dari kotoran yang menempel untuk meningkatkan keberhasilan penetasan

\subsection{Analisis Kebutuhan Perangkat Keras}

Dalam perancangan dan implementasi alat penetas telur bebek berbasis arduino, membutuhkan:

Tabel 1. Alat dan Kebutuhan

\begin{tabular}{cl}
\hline \multicolumn{1}{c}{ Alat } & \multicolumn{1}{c}{ Keterangan } \\
\hline Perangkat Keras (Hardware) & Perangkat keras (hardware) interface yang mempunyai spesifikasi minimal \\
& yaitu Intel Core i3; Processor 2,20 GHz, Hard disk : 320 GB, RAM 2 GB, \\
& Monitor LCD 14“ serta Keyboard dan Mouse \\
Microcontroller & Mikrokontroler adalah mikroprosesor yang dikhususkan untuk \\
& instrumentasi dan kendali. Mikroprosesor merupakan suatu alat elektronika \\
& digital yang mempunyai masukan dan keluaran serta kendali dengan \\
& program yang bisa ditulis dan dihapus dengan cara khusus. Mikrokontroler \\
& merupakan komputer didalam chip yang digunakan untuk mengontrol \\
& peralatan elektronik, yang menekankan efesiensi dan efiktifitas biaya[12]. \\
& Mikrokontroler merupakan suatu IC yang di dalamnya berisi CPU, ROM, \\
& RAM, dan I/O. Dengan adanya CPU tersebut maka mikrokontroler dapat \\
& melakukan proses berfikir berdasarkan program yang telah diberikan \\
\hline
\end{tabular}




\begin{tabular}{|c|c|}
\hline Alat & Keterangan \\
\hline & $\begin{array}{l}\text { kepadanya. Mikrokontroler banyak terdapat pada peralatan elektronik yang } \\
\text { serba otomatis, mesin fax, dan peralatan elektronik lainnya. Mikrokontroler } \\
\text { dapat disebut pula sebagai komputer yang berukuran kecil yang berdaya } \\
\text { rendah sehingga sebuah baterai dapat memberikan daya[13]. }\end{array}$ \\
\hline Arduino & $\begin{array}{l}\text { Arduino adalah sebuah komputer kecil yang dapat diprogram sebagai input } \\
\text { dan output dengan bantuan alat sebagai hasilnya. Arduino pertama kali } \\
\text { ditemukan pada tahun } 2005 \text { oleh Massimo Banzi dan David Cuartielles yang } \\
\text { mencoba membuat sebuah proyek untuk membuat perangkat untuk } \\
\text { mengendalikan dari proyek yang dibuat oleh mahasiswa pada waktu itu } \\
\text { dengan harga yang lebih murah dari harga perangkat yang tersedia pada saat } \\
\text { itu[14]. }\end{array}$ \\
\hline ATMega328 & $\begin{array}{l}\text { Mikrokontroler yang dipakai pada penelitian ini adalah ATmega328. } \\
\text { Mikrokontroler ATmega328 yang dikonversi menjadi sebuah modul } \\
\text { Arduino UNO melalui proses burn bootloader. Burn bootloader adalah } \\
\text { proses pengisian suatu program operasi atau yang disebut dengan } \\
\text { bootloader pada sebuah mikrokontroler, sehingga dapat difungsikan seperti } \\
\text { modul Arduino[15]. }\end{array}$ \\
\hline Sensor Suhu DS18B20 & $\begin{array}{l}\text { Sensor suhu DS18B20 adalah Sensor suhu yang menggunakan interface one } \\
\text { wire, sehingga hanya menggunakan kabel yang sedikit dalam instalasinya. } \\
\text { Uniknya sensor ini bias dijadikan parallel dengan satu input. Artinya kita } \\
\text { bisa menggunakan Sensor ds } 18 \text { b20 lebih dari satu namun output sensornya } \\
\text { hanya dihubungkan ke satu Pin Arduino. Alasan ini membuat Sensor ini } \\
\text { banyak digunakan apalagi Sensor ini memiliki tipe waterproof, sehingga } \\
\text { Sensor ini bisa kita buat sebagai alat ukur dan kontrol pemanas air[16]. }\end{array}$ \\
\hline Sensor Kelembaban SHT11 & $\begin{array}{l}\text { Sensor SHT } 11 \text { merupakan sensor single chip dari sensirion yang dapat } \\
\text { mendeteksi suhudengan range }-40^{\circ} \mathrm{C}\left(-40^{\circ} \mathrm{F}\right) \text { sampai dengan } 123.8^{\circ} \mathrm{C} \\
\left(+254.9^{\circ} \mathrm{F}\right) \text { dan kelembaban relatif suatu ruang atau tempat dari } 0 \% \mathrm{RH} \\
\text { sampai } 100 \% \mathrm{RH} \text { dengan respon waktu } 50 \mathrm{~ms} \text {. Sensor ini memilki akurasi } \\
\text { pengukuran suhu hingga }+/--0.5^{\circ} \mathrm{C} \text { pada suhu } 25^{\circ} \mathrm{C} \text { dan akurasi pengukuran } \\
\text { kelembaban relatif hingga }+/-3.5 \% \mathrm{RH} \text {. SHT11 merupakan modul sensor } \\
\text { suhu dan kelembaban relatif dari Sensirion yang dapat digunakan sebagai } \\
\text { alat pengindera suhu dan kelembaban dalam aplikasi pengendali atau } \\
\text { pemantauan suhu dan kelembaban relatif ruangan. }\end{array}$ \\
\hline
\end{tabular}

\subsection{Desain Sistem}

Secara garis besar, perancangan alat penetas telur bebek ini terdiri dari Arduino, LCD 16x2, Module RTC DS1302, Sensor DS18B20 Temperature Probe Water Proof, Button, Sensor Kelembaban SHT11, Driver Lampu, Driver Kipas, Lampu 12 VDC, Kipas 12 VDC, serta Adaptor 12 VDC. Diagram blok dari perancangan alat penetas telur bebek ini ditunjukkan pada gambar 1 .

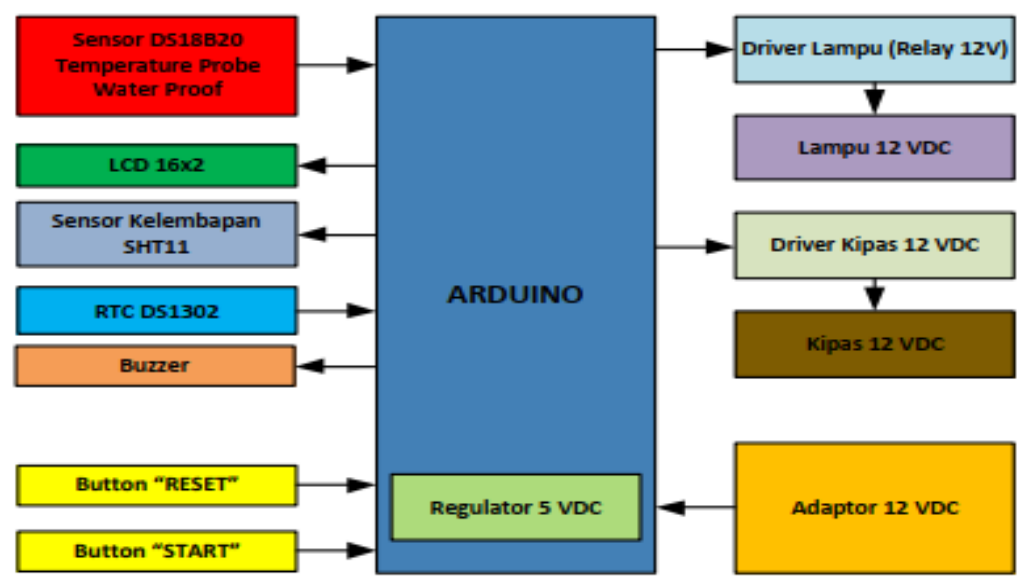

Gambar 1. Diagram Blok Rangkaian

\subsection{Perancangan System}

Perancangan alat penetas telur bebek berbasis arduino ini terdiri dari 2 bagian perancangan, yaitu perancangan secara elektronik dan perancangan secara mekanik.

a. Perancangan LCD 16x2 
JURNAL MEDIA INFORMATIKA BUDIDARMA

Volume 5, Nomor 2, April 2021, Page 431-438

ISSN 2614-5278 (media cetak), ISSN 2548-8368 (media online)

Available Online at https://ejurnal.stmik-budidarma.ac.id/index.php/mib DOI 10.30865/mib.v5i2.2816

Rangkaian LCD berfungsi untuk menampilkan data berupa waktu (tanggal dan jam) dan suhu aktual yang ada di dalam inkubator tersebut. Rangkaian LCD dapat dilihat pada gambar II berikut:

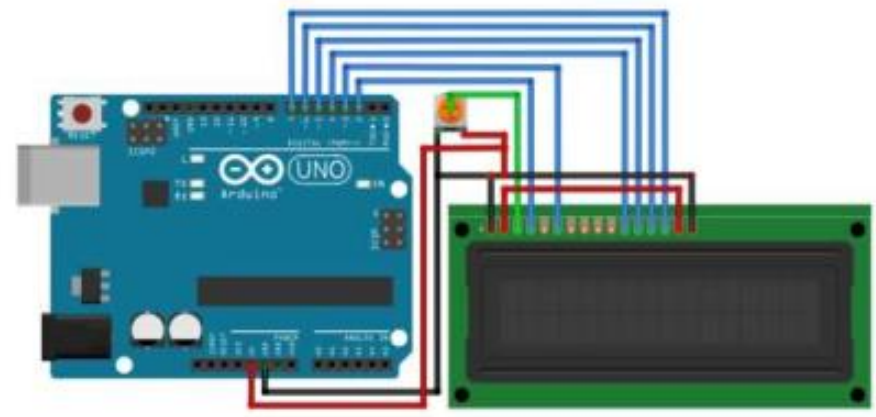

Gambar 2. Perancangan Rangkaian LCD 16x2 pada Arduino

b. Perancangan Rangkaian LCD $16 \times 2$ pada Arduino

Untuk pembacaan suhu, sensor menngunakan protokol 1 wire communication. DS18B20 memilki 3 pin yang terdiri dari $+5 \mathrm{~V}$, Ground dan Data Input/Output.Temperature sensor DS18B20 beroperasi pada suhu $-55^{\circ}$ celcius hingga $+125^{\circ}$ celcius. Keunggulan DS18B20 yaitu output berupa data digital dengan nilai ketelitian $0.5^{\circ}$ celcius selama kisaran temperature $10^{\circ}$ celcius sampai $+85^{\circ}$ celcius hingga mempermudah pembacaan oleh mikrokontroller. Dalam pemograman DS18B20, terdiri atas library OneWire.cpp dan OneWire.h.

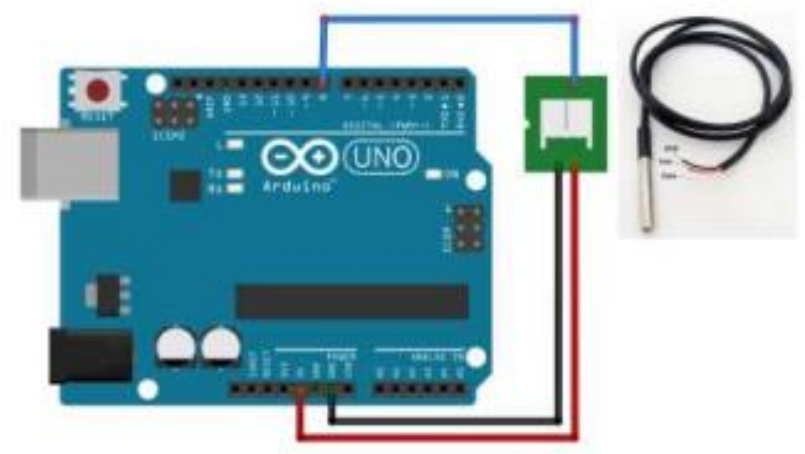

Gambar 3. Perancangan Rangkaian BS18B20

c. Perancangan Sensor Kelembaban SHT11

DHT11 termasuk sensor yang memiliki kualitas terbaik, dinilai dari respon, pembacaan data yang cepat, dan kemampuan anti-interference. Ukurannya yang kecil, dan dengan transmisi sinyal hingga 20 meter, membuat produk ini cocok digunakan untuk banyak aplikasi-aplikasi pengukuran suhu dan kelembaban.

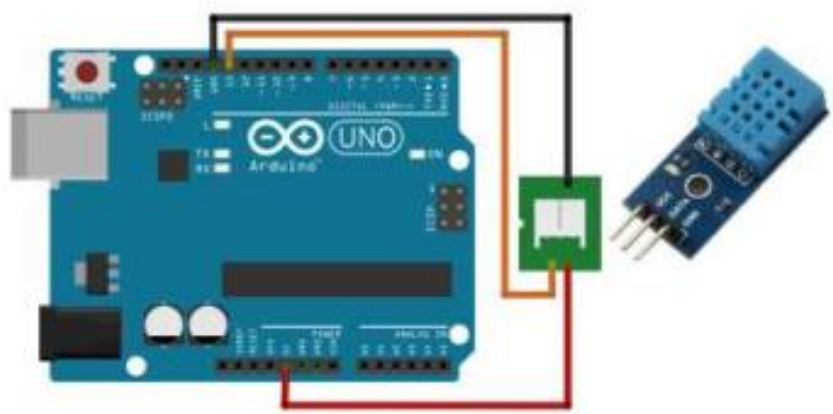

d. Flowchart

Gambar 4. Perancangan Rangkaian SHT11

Agar dapat melihat struktur jalannya program maka dibuat flowchart (diagram alur). Flowchart digunakan sebagai dasar acuan dalam membuat program. Struktur program akan lebih mudah dibuat atau didesain. Selain itu juga jika terdapat kesalahan akan lebih mudah untuk mendeteksi letak kesalahannya serta untuk lebih memudahkan dalam menambahkan instruksiinstruksi baru pada program jika nantinya terjadi pengembangan pada struktur programnya. Berikut adalah flowchart dari perancangan dan implementasi alat penetas telur bebek berbasis arduino: 
JURNAL MEDIA INFORMATIKA BUDIDARMA

Volume 5, Nomor 2, April 2021, Page 431-438

ISSN 2614-5278 (media cetak), ISSN 2548-8368 (media online)

Available Online at https://ejurnal.stmik-budidarma.ac.id/index.php/mib DOI 10.30865/mib.v5i2.2816

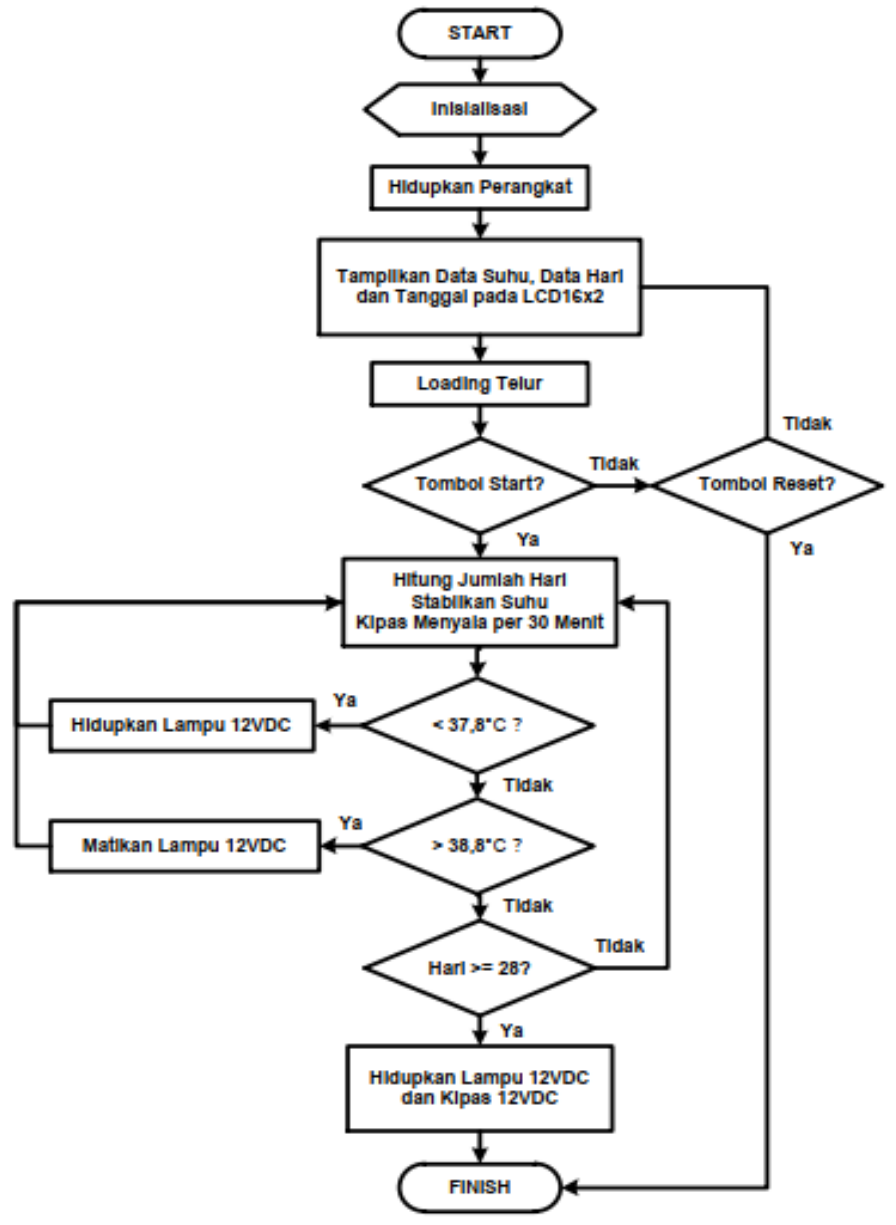

Gambar 5. Flowchart Perancangan

\section{HASIL DAN PEMBAHASAN}

Adapun hasil dari pengujian yang dilakukan adalah perangkat elektronik yang dibuat atau dirancang dan diprogram dengan menggunakan aplikasi Arduino IDE.

\section{Pengujian Hardware}

Setelah semua rangkaian yang telah selesai dirancang pada perancangan dan implementasi alat penetas telur bebek berbasis arduino, kemudian dilakukan penyatuan semua rangkaian yang telah selesai. Berikut adalah gambar hasil dari perancangan sistem eletronik ditunjukan oleh gambar 6 di bawah ini:

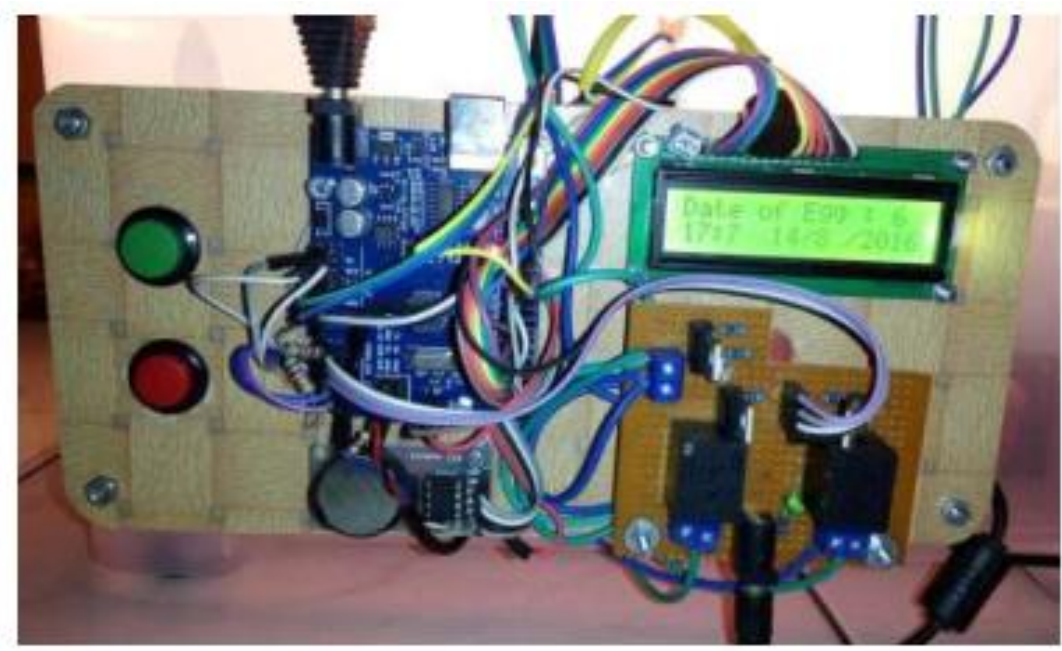

Gambar 6. Keseluruhan dari Hardware Elektronik 
2. Pengujian Rangkaian Sensor Suhu DS18B20

Pengujian bagian Sensor Suhu DS18B20 ini dilakukan dengan melakukan pengukuran dan perbandingan menggunakan thermometer, dalam hal ini digunakan thermometer ruangan. Hasil dari pengujian dan pengukuran ditunjukan pada tabel di bawah ini:

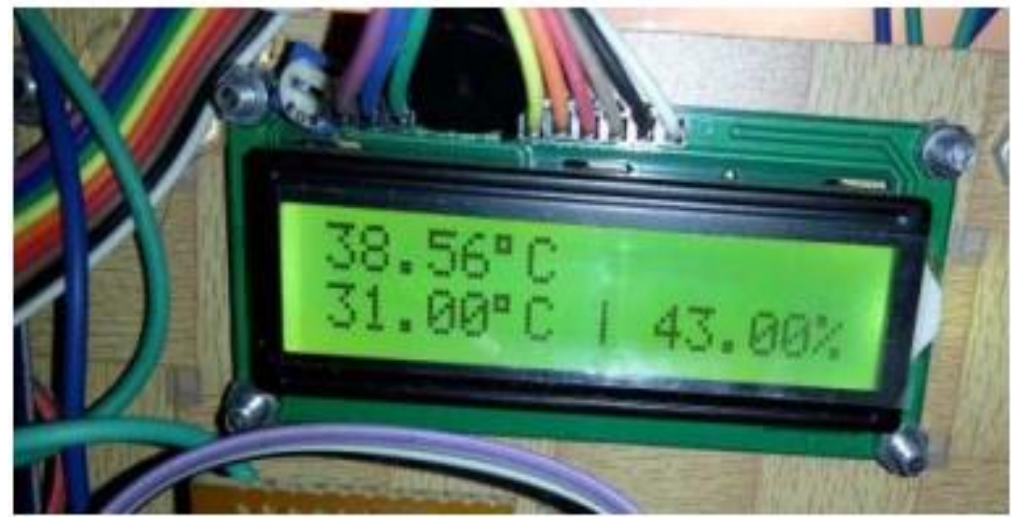

Gambar 7. Hasil Sensor Suhu DS18B20

Tabel. 2 Perbandingan Pengukuran Suhu DS18B20 dengan Thermometer

\begin{tabular}{cccc}
\hline $\begin{array}{c}\text { No. } \\
\text { Pengujian } \\
(\mathbf{n})\end{array}$ & $\begin{array}{c}\text { DS18B20 } \\
\left({ }^{\mathbf{0}} \mathbf{C}\right)\end{array}$ & $\begin{array}{c}\text { Thermometer } \\
\left({ }^{\mathbf{0}} \mathbf{C}\right)\end{array}$ & $\begin{array}{c}\text { Selisih } \\
\text { Error } \\
\left({ }^{\mathbf{0}} \mathbf{C}\right)\end{array}$ \\
\hline $\mathbf{1}$ & 35.1 & 35 & 0.1 \\
$\mathbf{2}$ & 29.8 & 30 & 0.2 \\
$\mathbf{3}$ & 28 & 28.5 & 0.5 \\
$\mathbf{4}$ & 38.2 & 38 & 0.2 \\
$\mathbf{5}$ & 39.2 & 39 & 0.2 \\
$\mathbf{6}$ & 31.2 & 31.5 & 0.3 \\
$\mathbf{7}$ & 40.1 & 40 & 0.1 \\
$\mathbf{8}$ & 29.2 & 29.5 & 0.3 \\
$\mathbf{9}$ & 30.1 & 30 & 0.1 \\
$\mathbf{1 0}$ & 32 & 32 & 0.15 \\
& Error $=\sum$ error / n Data & $\mathbf{0 . 1 5}$ \\
\hline
\end{tabular}

Berdasarkan data dari tabel di atas, dapat disimpulkan bahwa error dari sensor suhu DS18B20 dengan thermometer ruangan memiliki selisih error sebesar $\pm 0.15{ }^{\circ} \mathrm{C}$ pada 10 kali pengujian (n). Hasil pengujian secara jelas dapat dilihat pada gambar grafik di bawah ini. Terlihat hasil kedua pengujian hampir sama dengan selisih nilai pengukuran yang kecil. Kesimpulan dari pengujian ini adalah sensor suhu DS18B20 dapat dinyatakan akurat jika dibandingkan dengan pengukuran melalui thermometer ruangan.

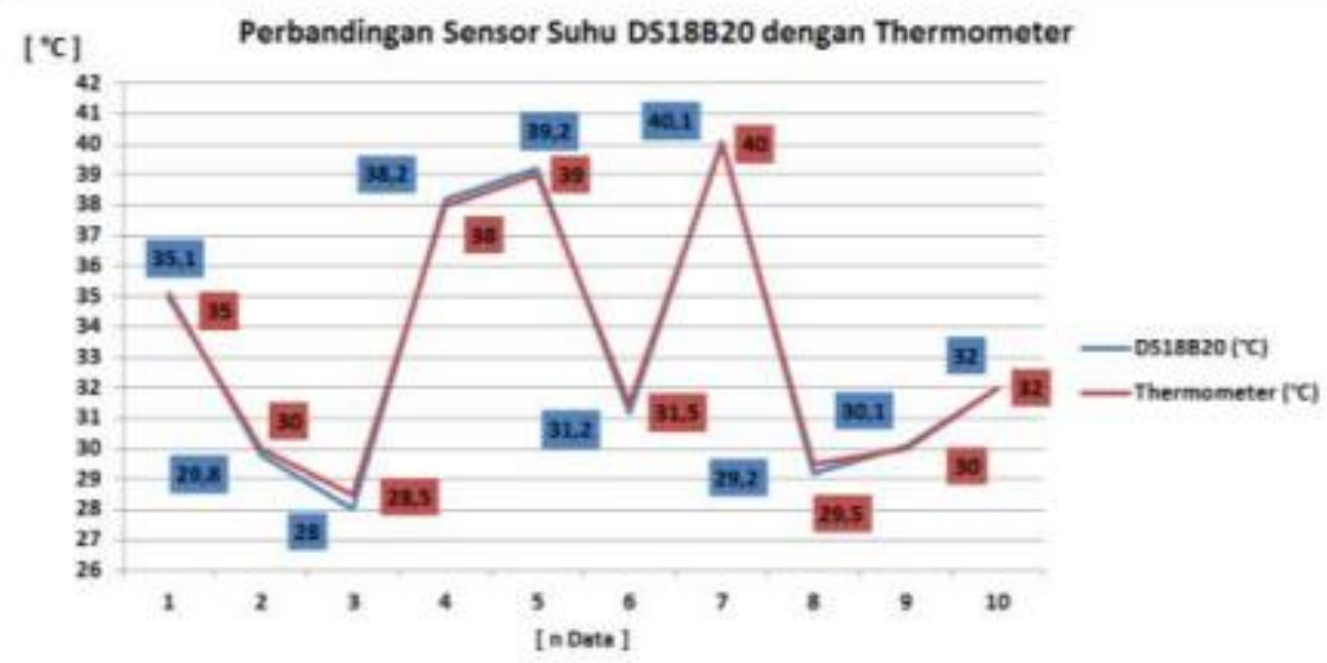

Gambar 8. Grafik Perbandingan Suhu 
Pengujian ini dilakukan untuk mengetahui apakah perangkat penetasan telur bekerja sesuai dengan logika program. Logika program pertama adalah penyesuaian suhu perangkat agar tidak melebih dari $39^{\circ} \mathrm{C}$. Jika suhu lebih besar dari $39^{\circ} \mathrm{C}$, maka perangkat akan otomatis menonaktifkan lampu $12 \mathrm{VDC}$ untuk tidak menambah suhu perangkat. Jika suhu optimal atau suhu di bawah atau sama dengan dari $39^{\circ} \mathrm{C}$, maka lampu $12 \mathrm{VDC}$ akan menyala untuk menambah suhu perangkat.

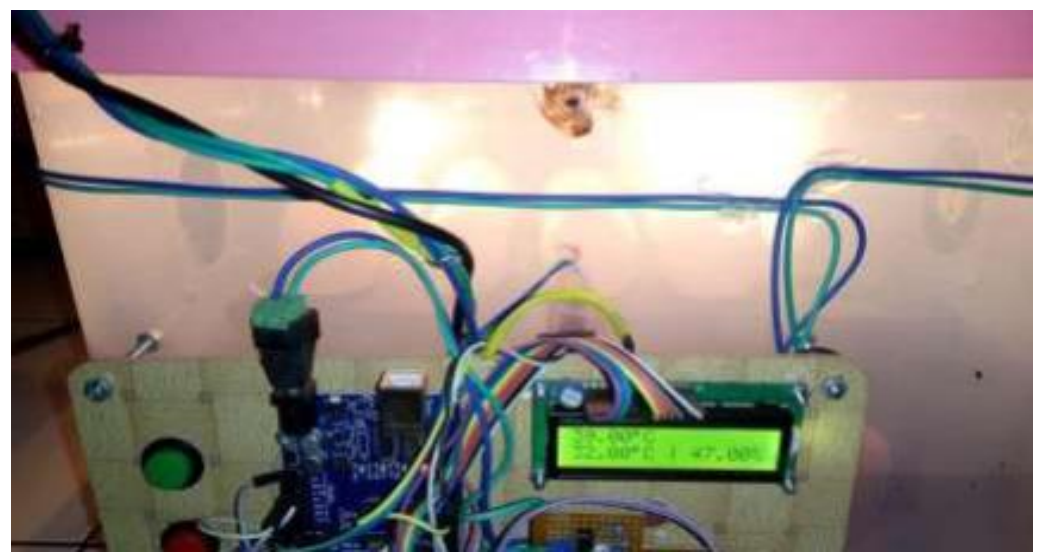

Gambar 9. Keadaan Suhu $\leq 39^{\circ} \mathrm{C}$

Logika program berikutnya adalah pengoperasian kipas 12VDC setiap 30 menit sekali untuk menjaga kelembaban perangkat Logika program berikutnya adalah perhitungan hari. Perangkat dilengkapi dengan 2 tombol, yaitu tombol start (hijau) dan tombol reset (merah). Jika tombol hijau ditekan, maka perangkat akan menghitung hari (dimulai dengan hari pertama [Date of Egg : 1] pada LCD 16x2). Jika jam menunjukan pukul 00.00, maka variabel perhitungan hari bertambah menjadi 2, dan seterusnya. Data perhitungan hari akan disimpan didalam EEPROM. Jika hari sudah memasuki hari ke 28, perangkat akan berada dalam keadaan stanby atau tetap menyesuaikan suhu tetapi tidak menghitung hari lagi.

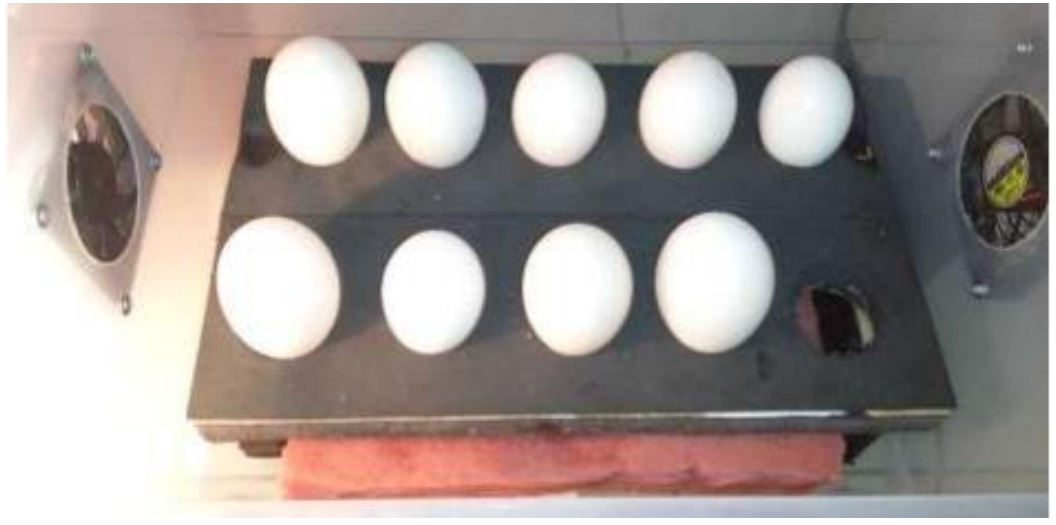

Gambar 10. Hasil Uji Sensor Kelembaban SHT11

Setelah dilakukan pengujian perangkat penetasan telur hingga hari ke-20. Pengujian pertama dihasilkan telur tidak berkembang dan pengujian dinyatakan gagal dikarenakan telur tidak steril atau telur yang tidak dibuahi sehingga tidak dapat menetas.

\section{KESIMPULAN}

Dari perancangan dan implementasi alat penetas telur bebek berbasis arduino kemudian dilakukan pengujian dan analisanya beberapa kesimpulan seperti: Perangkat dapat mengontrol suhu tidak melebihi dari $39{ }^{\circ} \mathrm{C}$ untuk melakukan penetasan telur. Perangkat memiliki 2 tombol penggunaan, yaitu yaitu tombol start (hijau) untuk melakukan perhitungan hari penetasan dan tombol reset (merah) untuk menghentikan perhitungan hari penetasan. Variabel hari yang telah berjalan tetap tersimpan di dalam EEPROM (Electrically Erasable Programmable ReadOnly Memory) mikrokontroler sehingga jika terjadi pemutusan atau hilangnya sumber daya tegangan seperti mati listrik dan lain sebagainya. Kipas 12 VDC pada perangkat menyala setiap 30 menit dan padam pada 30 menit berikutnya. Kapasitas telur pada perangkat sebanyak 10 butir telur. Perangkat tetap dapat bekerja menyesuaikan suhu dan kelembaban walaupun setelah 28 hari waktu waktu perhitungan penetasan normal. Perangkat penetas telur bebek berbasis arduino bekerja menggunakan power supply 12 VDC 5A. Waktu pengujian cukup lama, yaitu membutuhkan 28 hari hingga telur menetas. Dibutuhkan setup time (waktu yang dibutuhkan untuk perangkat dapat menyesuaikan suhu yang sesuai) minimal 24 jam sebelum digunakan. 
JURNAL MEDIA INFORMATIKA BUDIDARMA

Volume 5, Nomor 2, April 2021, Page 431-438

ISSN 2614-5278 (media cetak), ISSN 2548-8368 (media online)

Available Online at https://ejurnal.stmik-budidarma.ac.id/index.php/mib

DOI 10.30865/mib.v5i2.2816

\section{UCAPAN TERIMAKASIH}

Terima kasih kepada Universitas Labuhanbatu (ULB), Universitas Negeri Padang (UNP) dan para pihak yang telah banyak membantu sehingga penelitian dapat diselesaikan dan artikel ini dapat diterbitkan.

\section{REFERENCES}

[1] A. Herawan and A. Fauzi, "Detektor Sensor Sht11 Sebagai Monitoring Suhu Dan Kelembaban Ruang Berbasis Mikrokontroler Atmega16a Di-Smart Avr System," Setrum Sist. Kendali-Tenaga-Elektronika-TelekomunikasiKomputer, vol. 7, no. 1, p. 36, 2018, doi: 10.36055/setrum.v7i1.3295.

[2] R. Hartono, M. Fathuddin, and A. Izzuddin, "Perancangan dan Pembuatan Alat Penetas Telur Otomatis Berbasis Arduino," Energy, vol. 7, no. 1, pp. 30-37, 2017.

[3] B. Kusumo and N. Azis, "Rancang Bangun Alat Penyiram Sayuran Hidroponik Menggunakan Arduino Mega 2560," vol. 5, pp. 124-128, 2021, doi: 10.30865/mib.v5i1.2584.

[4] Z. Lubis et al., "Kontrol Mesin Air Otomatis Berbasis Arduino Dengan Smartphone," Cetak) Bul. Utama Tek., vol. 14 no. 3, pp. 1410-4520, 2019.

[5] A. W. Purwandi, "Sistem Kendali Jarak Jauh Dengan Handphone Menggunakan Pengenal Suara Microsoft Sapi 5.3," J. ELTEK, vol. 11, no. 01, pp. 1693-4024, 2013.

[6] M. Khairul, A. Rosa, A. Surapati, and B. J. P. Sanjaya, "Monitoring dan Kendali Peralatan Listrik Rumah Berbasis Web Freehosting," Semin. Nas. Inov., p. 2018, 2018, [Online]. Available: http://elektro11unib.16mb.com.

[7] Q. Nada, A. Rahman, J. Teknik, F. Teknik, and U. S. Kuala, "Rancang Bangun Sistem Kendali Lampu Jarak Jauh Berbasis Arduino Uno dan Ethernet Shield."

[8] D. Risqiwati, "Rancang Bangun Sistem Monitoring Listrik Prabayar dengan Menggunakan Arduino Uno," Kinetik, vol 1, no. 2, 2016, doi: 10.22219/kinetik.v1i2.16.

[9] D. Prihatmoko, "Perancangan Dan Implementasi Pengontrol Suhu Ruangan Berbasis Mikrokontroller Arduino Uno," Simetris J. Tek. Mesin, Elektro dan Ilmu Komput., vol. 7, no. 1, p. 117, 2016, doi: 10.24176/simet.v7i1.495.

[10] B. Bin Dahlan, "Sistem Kontrol Penerangan Menggunakan Arduino Uno Pada Universitas Ichsan Gorontalo," Ilk. J. Ilm., vol. 9, no. 3, pp. 282-289, 2017, doi: 10.33096/ilkom.v9i3.158.282-289.

[11] S. P. D. Hernanto and N. Az, "Perancangan Sistem Pengendalian Suhu Kandang Ayam Dengan Logika Fuzzy," J. Maest., vol. 2, no. 1, pp. 241-245, 2019.

[12] Ade Septryanti and Fitriyanti, "Berbasis Mikrokontroler Arduino Menggunakan," Ranc. Bangun Apl. Kunci Pintu Otomatis Berbas. Mikrokontrol Arduino Menggunakan Smartphone Android, vol. 2, no. 2, pp. 59-63, 2017, [Online]. Available:

https://scholar.googleusercontent.com/scholar?q=cache:Wdcs4FzN0ZcJ:scholar.google.com/+pintu+otomatis+menggu nakan+arduino\&hl=en\&as $\_\mathrm{sdt}=0,5$

[13] E. W. S. Budianto, Ramadiani, and A. H. Kridalaksana, "Kelembaban Kandang Ayam Boiler Berbasis Mikrokontroler Atmega328," Pros. Semin. Nas. Ilmu Komput. dan Teknol. Inf., vol. 2, no. 2, pp. 70-73, 2017.

[14] K. Fatmawati, E. Sabna, and Y. Irawan, "Rancang Bangun Tempat Sampah Pintar Menggunakan Sensor Jarak Berbasis Mikrokontroler Arduino," Riau J. Comput. Sci., vol. 6, no. 2, pp. 124-134, 2020.

[15] I. M. N. Suardiana, I. R. Agung, and P. Rahardjo, "Rancang Bangun Sistem Pembacaan Jumlah Konsumsi Air Pelanggan Pdam Berbasis Mikrokontroler Atmega328 Dilengkapi Sms,” Maj. Ilm. Teknol. Elektro, vol. 16, no. 1, pp. 31-40, 2017, doi: 10.24843/mite.1601.05.

[16] M. Imam and E. Apriaskar, "PENGENDALIAN SUHU AIR MENGGUNAKAN SENSOR SUHU DS18B20 Computer Science / Industrial Engineering / Mechanic Engineering / Civil Engineering Computer Science / Industrial Engineering / Mechanic Engineering Civil Engineering,”vol. 06, no. 01, pp. 347-352, 2019. 